\title{
Equity-Based Compensation To Outside Directors And Accounting Conservatism
}

Kyunbeom Jeong, Korea Advanced Institute of Science and Technology (KAIST), Korea Hyungtae Kim, Korea Advanced Institute of Science and Technology (KAIST), Korea

\begin{abstract}
This paper examines the relationship between equity-based compensation to outside directors and accounting conservatism. Equity-based compensation to outside directors can strengthen the firm's corporate governance structure. Since this strong governance reduces the information asymmetry between managers and shareholders, it is also possible that firms with strong governance use more conservative accounting. To test this prediction, we investigate whether the proportion of the equity-based compensation to total compensation to outside directors has an effect on the level of conservatism and the various measures that are used. We find that there is a positive relationship between the proportion of equity-based compensation and the level of conservatism. The results are robust to additional tests using alternative measures of the equitybased compensation (the amount of the equity-based compensation) and the equity-based compensation to audit committee members instead of the full board of directors. According to our findings, we can conclude that equity-based compensation to outside directors encourages directors to put more effort into reducing the information asymmetry using conservative accounting.
\end{abstract}

Keywords: Equity-based Compensation; Accounting Conservatism; Information Asymmetry; Corporate Governance

\section{INTRODUCTION}

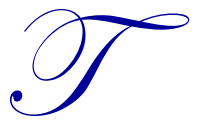

his paper investigates the relationship between equity-based compensation to outside directors and accounting conservatism. Recently, research focused on equity-based compensation to outside directors has sharply increased (e.g., Ryan and Wiggins, 2004). Recent evidence shows that equitybased compensation to outside directors makes them more align with the shareholders, so it strenthens corporate governance in the firm(e.g., Yermack, 2004; Fich and Shivdasani, 2005). And it is already clarified that strong corporate governance can effectively mitigate the information asymmetry between managers and shareholders by improving financial reporting transparency and encouraging voluntary disclosures of better quality information (e.g., Ajinkya et al., 2005; Karamanou and Vafeas, 2005). Meanwhile, conservative accounting is another way to reduce the information asymmetry. Accounting conservatism helps reduce agency costs arising from asymmetric information, such as payoff functions and limited liability (e.g., Watts, 2003; Watts, 2006). Therefore, firms with higher corporate governance have incentives to conservatively recognize their earnings in order to reduce information asymmetry.

However, there is no research about the effect of equity-based compensation to outside directors on accounting conservatism. As we mentioned above, accounting conservatism is one way to reduce agency costs or information asymmetry, and the board of directors also tries to reduce this information asymmetry. Equity-based compensation to outside directors provides incentives for mitigating the information asymmetry between managers and shareholders due to the alignment of the interests of outside directors and shareholders. So, it is possible to think that outside directors motivated by compensating equity-based compensation are more likely to use conservative accounting. 
Extant literature has mainly focused on the effect of equity-based compensation for outside directors on general corporate governance measures, or the effect of these general corporate governance mechanisms on accounting conservatism. However, in this paper, we try to investigate the influence of equity-based compensation for outside directors on accounting conservatism. In other words, we examine whether outside directors motivated by equity-based compensation encourage managers to recognize their earnings more conservatively. Previous studies already investigated the effect of general director characteristics (e.g., Beekes et al., 2004; Ahmed and Duellman, 2007) on accounting conservatism. However, we not only investigate these general characteristics, but also the effect of compensation strategies. We examine whether the compensation strategy - equity-based compensation to outside directors - has an effect on the level of conservatism using various measures of accounting conservatism.

Our tests use three specific measures and two composite measures to increase the validity and the credibility of the proxies: a firm-year measure (C-score) based on the Basu model (1997) following Khan and Watts (2009), an accrual-based measure following Givoly and Hayn (2000), a market-based measure following Beaver and Ryan (2000), and the average values of these three individual measures, and the latter two individual measures. Using these various measures of accounting conservatism, we perform tests investigating whether the proportion of equity-based compensation to total compensation affects the level of conservatism. Additionally, we also test whether the amount of equity-based compensation given to each outside directors influences the level of conservatism, and whether the proportion and amount of equity-based compensation to audit committee members affects the conservatism level. Overall, we find that the proportion of equity-based compensation to outside directors is positively associated with the level of conservatism.

Our findings provide evidence that equity-based compensation to outside directors encourages the level of accounting conservatism. Firms using a compensation scheme that utilizes a higher level of equity-based compensation for outside directors are positively related to using more conservative accounting. Specifically, firms that activate their outside directors with a higher amount of equity-based compensation causes managers to recognize their earnings conservatively. Results are robust in tests that use the amount value of equity-based compensation and the proportion and amount of equity-based compensation to audit committee members. In short, these results support our hypothesis that interest alignment between shareholders and outside directors enhances corporate governance and encourages the use of accounting conservatism in order to reduce information asymmetry problems.

This paper contributes to the existing literature in two ways. First, we find a link between the compensation structure of outside directors and accounting conservatism. We newly provide evidence of the effect of equity-based compensation to outside directors on accounting conservatism. This evidence is important because accounting conservatism is one of the most frequently treated issues in accounting research and the interest in the equity-based compensation for outside directors also has dramatically increased. Second, this study extends the extant literature that investigates the relationship between corporate governance and accounting conservatism, as mentioned by Ahmed and Duellman (2007). Ahmed and Duellman (2007) find that the percentage of outside directors and the percentage of the ownership of outside directors are positively associated with conservatism. We extend their research by presenting the effect of the specific compensation structure to outside directors on accounting conservatism. However Ahmed and Duellman (2007) only document just the effect of the general characteristics of outside directors on conservatism.

The remainder of the paper is documented as follows. The related research and our hypotheses are discussed in Section 2. In section 3, we describe the sample and the research design. Section 4 presents the results, sensitivity analyses are discussed in section 5, and we summarize our findings and conclude our study in section 6 .

\section{RELATED RESEARCH AND HYPOTHESES}

There exists information asymmetry between managers and shareholders due to a separation of management and ownership. Agency problems arise from this information asymmetry (e.g., Jensen and Meckling, 1976). One of the effective ways to reduce these agency problems is through the governance structure. Strong governance can reduce information asymmetry between managers and shareholders by improving financial 
reporting transparency and encouraging voluntary disclosures of better quality information (e.g., Ajinkya et al., 2005; Karamanou and Vafeas, 2005). Strong corporate governance assists analysts in forecasting earnings more accurately. Consequently, it provides better quality information to the investors (e.g., Beekes and Brown, 2006; Ali et al., 2007). Corporate governance can improve the informativeness of earnings in terms of the correlation between earnings and returns (e.g., Vafeas, 2000; Yeo et al., 2002; Ahmed et al., 2006). And better governance helps to detect or prevent earnings management by monitoring managers' opportunistic behavior (e.g., Klein, 2002; Xie et al., 2003; Bedard et al., 2004; Davidson et al., 2005). Conclusively, greater levels of corporate governance reduce the information asymmetry between managers and shareholders by restricting managers' opportunistic behavior.

The board of directors plays a key role in corporate governance. It oversees managers to prevent their opportunistic behavior due to the fact that their interests are different than those of the shareholders. Thus, it causes managers to increase information quality by monitoring their disclosure activities (e.g., Fama and Jensen, 1983). Thus, many studies deal with the effectiveness of the board of directors as a governance mechanism. Yermack (1996) says that smaller boards have generally been considered to be more effective in their decision making process. Beasley (1996) points out that financial statement fraud is less likely to occur when there are more outside directors. Vafeas (1999) reports that more frequent board meetings are associated with better future operating performance. Ajinkya et al. (2005) confirm that firms with more outside directors and institutional ownership issue higher quality management forecasts. And also, Karamanou and Vafeas (2005) reports that when the firms have more effective boards and audit committees, managers are more likely to issue and update their management forecasts.

This prior research tells us that the board of directors, especially outside directors can perform a role in reducing information asymmetry and agency problems caused by the conflict of interest between managers and shareholders. However, directors are also agents that represent the shareholders. They sometimes collude with managers and pursue their own benefits. Therefore, another agency problem can exist between directors and shareholders. To mitigate this secondary agency problem, we need to find a mechanism that aligns the interests of directors to shareholders.

Prior studies show that equity-based compensation for managers influences the financial reporting quality and firm value by aligning their interests with the shareholders'. Nagar et al. (2003) show that managers with more equity-based compensation are likely to issue more management forecasts and these forecasts have better quality since their interests are more aligned with shareholders'. Armstrong et al. (2009) provide some evidence that accounting irregularities less frequently occurs at firms where CEOs have relatively higher levels of equity incentives. Bergstresser and Phillippon (2006) find that managers with higher equity-based compensation are more interested in firm value. In sum, equity-based compensation for managers improves the corporate governance levels, then mitigates the agency problem between managers and shareholders.

In a similar vein, equity-based compensation for directors can also resolve the secondary agency problem between directors and shareholders. Equity-based compensation for directors improves corporate governance, because it mitigates barriers caused by different utility function from shareholders, and improves directors' incentives to maximize shareholder wealth (e.g., Maug, 1997). In these days, more research on equity-based compensation for directors is rigorously conducting. This mainly deals with the equity-based compensation for outside directors since outside directors play an important role in the board of directors. ${ }^{1}$

Ryan and Wiggins (2004) show that equity-based compensation to outside directors is positively related to the level of corporate governance. They find that independent directors that have bargaining power over the CEO receive more equity-based compensation, are more closely aligned with shareholders' objectives. Perry (2000) confirms the positive effect of equity-based compensation for outside directors on corporate governance by documenting the positive relationship between equity-based compensation for outside directors and CEO turnover following poor firm performance. Linn and Park (2005) also find that firms use the equity-based compensation for outside directors when strong governance is required. They provide evidence that firms with more investment

\footnotetext{
1 There are three types of directors, i.e., inside, gray and outside directors. We only focus on outside directors. Outside directors do not have any relation with the CEO, they only have director position, however, other types of directors do not. So they are relatively free from CEO control than other types.
} 
opportunities pay a higher level of compensation to their outside directors than firms with fewer investment opportunities. Also, there are some studies that directly examine the effect of equity-based compensation for outside directors on the firm value. If equity-based compensation for outside directors really matters to corporate governance, it should have some impact on firm value. Cordeiro et al. (2005) shows that investigate that equitybased compensation to outside directors is positively related to future firm performance. Fich and Shivdasani (2005) also suggest that equity-based compensation increase firm value by aligning the incentives of outside directors and shareholders.

As described, outside directors play a role in resolving the information asymmetry problem and representing the shareholders' aspect. Equity-based compensation improves the level of corporate governance by aligning directors' incentives with shareholders'. Firms with strong governance and well-motivated directors have less information asymmetry. These directors will affect to the level of accounting conservatism since conservative accounting is also another way to reduce information asymmetry.

Basu (1997) defines conservatism as the asymmetric timeliness of earnings. He interprets conservatism as asymmetric recognition between 'bad news' and 'good news'. It means conservative firms recognize 'bad news' in a more timely manner than 'good news' in their earnings. Watts $(2003,2006)$ says that accounting conservatism helps reduce agency costs arising from asymmetric information, such as payoff functions and limited liability. Watts (2003) argues that the board of directors is interested in conservatism, because conservatism can restrict managers' tendency to over-compensate themselves by using aggressive accounting, or reporting good news more than bad news. LaFond and Watts (2008) also show that conservatism can reduce information asymmetry by disclosing negative information faster in the form of earnings.

As we mentioned above, conservatism can be another method of reducing the information asymmetry between managers and shareholders. And strong corporate governance also can reduce information asymmetry. Then, do firms with strong governance use more conservative accounting or less conservative accounting? With regard to this question, Beekes et al. (2004) examine board independence and accounting conservatism, and find a positive relationship between them. Ahmed and Duellman (2007) also investigate the relationship between board of director characteristics and accounting conservatism. They provide evidence that the firms with strong governance structure, measured by the proportion of the outside directors and the percentage of outside directors' ownerships, use more conservative accounting in order to reduce the agency costs. As a specific characteristic of the board, Krishnan and Visvanathan (2008) find that the audit committee directors' accounting expertise positively affects to the accounting conservatism, due to improved effectiveness of the audit committee. Summarizing these previous results, firms with strong corporate governance provide their accounting numbers more conservatively to reduce information asymmetry because managers of these firms are more on the shareholders' side.

There are some studies examining the association between corporate governance and accounting conservatism, but there is no research that concerns the equity-based compensation for the directors as a way of encouraging more conservative accounting. Therefore, we investigate the relationship between equity-based compensation for directors, particularly outside directors, and accounting conservatism. As we mentioned in the front part of this section, firms with more equity-based compensation for the board members strengthens the level of corporate governance, by reducing the secondary agency problem between directors and shareholders. Thus, we predict that equity-based compensation for outside directors is positively associated with the level of accounting conservatism.

\section{RESEARCH DESIGN}

\subsection{Sample and Data}

Our sample consists of firms from the Compustat, CRSP and Corporate Library databases for the years extending from year 2006 to 2008. ${ }^{2}$ Compustat (ЕхесиСотр) provides annual compensation data for each outside director after 2006 as well as other financial data. Since Compustat does not provide information regarding the

\footnotetext{
${ }^{2}$ Due to data insufficiency, we set our sample period from year 2006 to 2008. 
different types of directors, we consulted the Corporate Library database. Directors are classified as one of the following: inside, gray, or outside. ${ }^{3}$ To fill in the data missing from the Corporate Library database, we handcollected additional director type information from the proxy statements. In regards to the stock price information, we obtained the necessary data from the $C R S P$ database. After all variables are accounted for, the final sample for our empirical analysis comprises 3,104 firm-year observations from the combination of the Compustat, CRSP and Corporate Library databases. ${ }^{4}$

\subsection{Empirical Model}

We use the following $O L S$ regression model (with the detailed subscripts omitted).

$$
\begin{aligned}
C O N= & \beta_{0}+\beta_{1} \text { DIR_COMP }+\beta_{2} C E O \_C O M P+\beta_{3} \text { CEOICHAIR }+\beta_{4} \text { OUTSIDE }+ \\
& \beta_{5} \text { BOARDSIZE }+\beta_{6} \text { AUDITSIZE }+\beta_{7} \text { TOPOWN }+\beta_{8} \text { SIZE }+ \\
& \beta_{9} D E B T+\beta_{10} C F O+\beta_{11} \text { CSALES }+\beta_{12} \text { LITI }+\beta_{13} \text { BIG }+\varepsilon .
\end{aligned}
$$

The dependent variable, CON, stands for the conservatism level. We apply three types of specifications (one is for conditional conservatism, the others are for unconditional conservatism) and two types of composite measures to increase the validity and the credibility of the proxies.

Our first measure of conservatism is CSCORE, which comes from Khan and Watts (2009). According to Watts (2003a), conservatism is related to four factors, i.e., contracts (including debt and compensation contracts), litigation, taxation and regulation. Khan and Watts (2009) argue that variations in conservatism can be captured by these factors. Further, they parsimoniously identify three variables that represent these four factors. They are market-to-book ratio, size, and leverage. The biggest advantage of CSCORE is that we can calculate the firm-year measure of conservatism from Basu model (1997), which was impossible before.

Our second measure of conservatism is CONACC, which is based on the concept that conservative accounting generates consistently negative accruals by accelerating bad news and decelerating good news (e.g., Givoly and Hayn, 2000). To compute this measure, we first calculate the values of total accruals (income before extraordinary items - cash flows from operations + depreciation expense) divided by average total assets (Ahmed et al. 2002). We take the mean of the numbers over three years, centered on year t. By averaging the values, we can reduce the possible temporary effects on accruals since these transient elements are likely to disappear within two years (e.g., Richardson et al., 2005). Then we multiply negative one (-1) so that a larger CONACC value implies a greater level of conservatism.

Our third measure of conservatism is CONBM. Conservative firms tend to underestimate the book value of equity compare to the market value of equity. For this reason, these firms will have a lower level of book-to-market ratio. Following the idea, we set CONBM as the book-to-market ratio multiplied by negative one (-1), since we want a higher value for the measure to indicate a higher level of conservatism (e.g., Beaver and Ryan, 2000).

The last two conservatism measures are CONRANK1 and CONRANK2. Because all the three measures above individually have some errors in gauging conservatism level, we develop two aggregate measures as follows (e.g., Hui et al., 2009). First, we order the rank of each firm's conservatism level three times based on CSCORE, CONACC and CONBM, respectively. CONRANKI indicates the average value of the three ranks regardless of whether the measures denote conditional or unconditional conservatism. And CONRANK2 implies the average value of the two ranks of unconditional conservatism measures (i.e., CONACC and CONBM). The reason we adopt the mean of the rank values is that the mean of the raw values might be biased by a dominant or extreme values. However, using the rank values allow us to mitigate these possible biases.

\footnotetext{
3 An inside director holds a director position in a firm and is also an employee of the firm at the same time. A gray director holds a director position in a firm and has a special relationship with the CEO. Since a gray director is usually a former employee, current commercial partner or family member of the CEO, he (she) may be easily influenced by the CEO. A director who does not satisfy either of these descriptions is called an outside director, and he (she) is independent of the CEO. We only consider independent directors in our analyses. However, we arrive at similar results when we include gray directors in our analyses.

4 To handle outlier problems, we winsorize continuous variables at the $1 \%$ and $99 \%$ levels.
} 
The independent variable DIR_COMP indicates equity-based compensation given to the outside directors. It is the ratio of total equity-based compensation to all outside directors over total compensation (cash and equity) to all outside directors (i.e., total equity-based compensation divided by total compensation). Since equity compensation to outside directors will tie the interests of directors and shareholders together, a higher proportion of equity compensation to outside directors will result in a higher level of conservatism. So, we expect $\beta_{1}$ to be positive. $C E O_{-} C O M P$ represents equity-based compensation to the CEO, which is also defined as the ratio of total equitybased compensation to the CEO over total compensation. According to the prior literature, managers' behavior varies. On the one hand, managers will care more about the shareholders due to the alignment in interests (e.g., Nagar et al., 2003); on the other hand, managers will care less about the shareholders. Rather they only focus on creating their own benefit (e.g., Aboody and Kasznik, 2000). Thus, we do not make any expectations on $\beta_{2}$. CEO/CHAIR, OUTSIDE, BOARDSIZE, AUDITSIZE and TOPOWN are corporate governance variables. CEO/CHAIR is 1 if a CEO is also a chairman of the board and 0 otherwise. The dual position of the CEO and Chairman usually creates weak corporate governance since board members' monitoring activities will be restricted by the CEO. We guess $\beta_{3}$ to be negative. OUTSIDE is the proportion of outside directors on the board. More outside directors intensify the corporate governance, and we anticipate positive coefficients on $\beta_{4}$ (e.g., Ajinkya et al., 2005; Klein, 2002, etc.). BOARDSIZE is the number of directors on the board, and AUDITSIZE is the number of directors in the audit committee. These two variables are controversial since a larger board is sometimes efficient but sometimes not. In some cases, a larger board is more efficient since there are more directors to oversee managers, but in other cases, it is inefficient since there is a coordination problem among the directors (e.g., Yermack, 1996). So, we do not expect any specific directions on $\beta_{5}$ and $\beta_{6}$. TOPOWN is the percentage of total shares held by the top five executives to total outstanding shares. Managers who possess a larger number of shares are inclined to defend the shareholders' interests. That means as this number gets larger, earnings will become more credible. Therefore, we hypothesize positive coefficients on $\beta_{7}$ (e.g., Warfield et al., 1995).

Furthermore, we include other variables. SIZE represents firm size and is defined as the log of the market value of equity at the beginning of the year. DEBT is the ratio of long-term debt to total assets. $C F O$ is the ratio of the cash flow from operations to total assets. CSALES implies a change in sales (e.g., Ahmed et al., 2002). LITI is 1 for highly litigious industries (biotechnology, computers, electronics and retail) and 0 otherwise. Managers are cautious about litigation risk, and they tend to report more conservatively. We predict $\beta_{12}$ to be positive (e.g., Francis et al., 1994). BIG4 is 1 if the company is audited by one of the Big 4 auditors and 0 otherwise. The Big 4 auditors have a better reputation than non-Big 4 auditors, so they advise their client firms to report in a more conservative way. For this reason, we expect $\beta_{13}$ to be positive (e.g., Basu et al., 2000).

\section{RESULTS}

\subsection{Descriptive statistics}

In Table 1, we introduce the descriptive statistics on key variables. Our sample period is from year 2006 to 2008. Descriptive statistics for the variables are from the 3,104 firm-year level observations. On average, outside directors in a firm receive approximately $52 \%$ of their total compensation in stock or options. In dollar terms, each outside director is granted $\$ 100,000$ of equity-based compensation on average. On the other hand, CEOs are rewarded with much more stock or options than outside directors. They receive $65 \%$ of total compensation and approximately $\$ 4.1$ million as equity-based compensation. The mean value of CEO/CHAIR (0.5515) implies that CEOs of $55 \%$ of the firm-years hold a chairman position at the same time in our sample. Among the board of directors, $75 \%$ are outside members (mean of OUTSIDE: 0.7450). The number of board members varies from 5 to 15 and there are 9 members on average (mean of BOARDSIZE: 2.1831). Moreover, the number of audit committee members ranges from 2 to 7 and there are 3 members in the audit committee on average (mean of AUDITSIZE: 1.3011). The top five managers hold $2.92 \%$ of the shares of the firm (mean of TOPOWN: 2.9152). Additionally, the other control variables appear to have similar distribution to those found in the prior literature. 
Table 1: Descriptive Statistics on Independent and Control Variables

\begin{tabular}{|c|c|c|c|c|c|c|c|c|}
\hline & \# of obs. & Mean & Median & Stdev. & Min & $25 \%$ & $75 \%$ & Max \\
\hline \multicolumn{9}{|l|}{ Independent Variables } \\
\hline$\overline{D I R \_C O M P}$ & 3,104 & 0.5219 & 0.5383 & 0.2121 & 0.0000 & 0.4055 & 0.6649 & 0.9612 \\
\hline$D I R \_R A M T(\$ 1,000)$ & 3,104 & 100 & 79 & 90 & 0 & 44 & 126 & 966 \\
\hline \multicolumn{9}{|l|}{ Control Variables } \\
\hline$\overline{C E O \_C O M P}$ & 3,104 & 0.6393 & 0.7234 & 0.2590 & 0.0000 & 0.5256 & 0.8261 & 0.9535 \\
\hline$C E O \_R A M T(\$ 1,000)$ & 3,104 & 4,099 & 2,459 & 4,827 & 0 & 940 & 5,455 & 25,735 \\
\hline CEO/CHAIR & 3,104 & 0.5515 & 1.0000 & 0.4974 & 0.0000 & 0.0000 & 1.0000 & 1.0000 \\
\hline OUTSIDE & 3,104 & 0.7450 & 0.7596 & 0.1320 & 0.1667 & 0.6667 & 0.8571 & 1.0000 \\
\hline BOARDSIZE & 3,104 & 2.1831 & 2.1972 & 0.2389 & 1.6094 & 2.0794 & 2.3979 & 2.7081 \\
\hline AUDITSIZE & 3,104 & 1.3011 & 1.3863 & 0.2503 & 0.6931 & 1.0986 & 1.3863 & 1.9459 \\
\hline TOPOWN (\%) & 3,104 & 2.9152 & 0.7586 & 6.2394 & 0.0148 & 0.2901 & 2.0319 & 36.6148 \\
\hline$S I Z E$ & 3,104 & 7.6461 & 7.5315 & 1.5242 & 4.5872 & 6.5493 & 8.6421 & 11.6186 \\
\hline$D E B T$ & 3,104 & 0.1874 & 0.1718 & 0.1642 & 0 & 0.0217 & 0.2900 & 0.7342 \\
\hline$C F O$ & 3,104 & 0.1079 & 0.1016 & 0.0754 & -0.1145 & 0.0630 & 0.1496 & 0.3300 \\
\hline CSALES & 3,104 & 0.0798 & 0.0191 & 0.1567 & -0.3266 & 0.0000 & 0.1342 & 0.7188 \\
\hline LITI & 3,104 & 0.1932 & 0.0000 & 0.3949 & 0.0000 & 0.0000 & 0.0000 & 1.0000 \\
\hline BIG4 & 3,104 & 0.9366 & 1.0000 & 0.2438 & 0.0000 & 1.0000 & 1.0000 & 1.0000 \\
\hline
\end{tabular}

$D I R \_C O M P$ = ratio of total equity-based compensation to outside directors over total compensation to outside directors in a firm during the fiscal year (i.e. total equity-based incentives / total incentives); DIR_RAMT = average amount of equity-based incentives to each director in a firm during the fiscal year; CEO_COMP = ratio of total equity-based compensation to CEO over total compensation to CEO; CEO_RAMT = total amount of equity-based incentives to CEO in a firm during the fiscal year; $C E O / C H A I R=1$ if the CEO also holds chairman of the board, and 0 otherwise; OUTSIDE = total number of independent outside directors over total number of directors; BOARDSIZE $=\log$ of total number of directors in a board; AUDITSIZE $=\log$ of total number of directors in audit committee; TOPOWN $=$ the percentage of total shares held by top five executives to total outstanding shares; $S I Z E=\log$ of total assets; $D E B T=$ ratio of total long-term debt to total assets; $C F O=$ ratio of cash flow from operations to total assets; CSALES = annual percentage change in sales; LITI = 1 for SIC 2833-2836, 3570-3577, 3600-3674, 7371-7379, and 8731-8734, and 0 otherwise; $B I G 4=1$ if a firm audited by big4 auditors, 0 otherwise.

Table 2: Descriptive Statistics on Dependent Variables

\begin{tabular}{|c|c|c|c|c|c|c|c|c|}
\hline & \# of obs. & Mean & Median & Stdev. & Min & $25 \%$ & $75 \%$ & Max \\
\hline \multicolumn{9}{|c|}{ Dependent Variables } \\
\hline$\overline{C S C O R E}$ & 3,104 & 0.0424 & 0.0461 & 0.1296 & -0.3603 & -0.0349 & 0.1177 & 0.3856 \\
\hline CONACC & 3,104 & 0.0149 & 0.0090 & 0.0328 & -0.0627 & -0.0031 & 0.0255 & 0.1394 \\
\hline CONBM & 3,104 & -0.5372 & -0.4500 & 0.4031 & -2.2977 & -0.6720 & -0.2810 & 0.1719 \\
\hline CONRANK1 & 3,104 & 1,553 & 1,545 & 459.12 & 258 & 1,231 & 1875 & 3075 \\
\hline CONRANK2 & 3,104 & 1,553 & 1,533 & 594.37 & 114 & 1,132 & 1941 & 3100 \\
\hline
\end{tabular}

CSCORE = conservatism measure in Khan and Watts (2009); CONACC = (income before extraordinary items - cash flows from operations + depreciation expense) divided by average total assets (e.g., Givoly and Hayn, 2000); CONBM = book-to-market ratio multiplied by negative one (-1) (e.g., Beaver and Ryan, 2000); CONRANK1 = Average rank of CSCORE, CONACC, and CONBM; CONRANK2 = Average rank of CONACC and CONBM;

Table 2 presents the descriptive statistics for dependent variables. The mean (median) values of CSCORE, CONACC and CONBM are 0.0424 (0.0461), 0.0149 (0.0090) and $-0.5372(-0.4500)$, respectively. CSCORE is consistent with Khan and Watts (2009) and CONACC and CONBM are also consistent with Ahmed and Duellman (2007). 


\subsection{Results for univariate tests}

The correlation coefficients for the independent and the dependent variables are shown in Table 3 . We selectively report the variables that are related to outside director compensation (DIR_COMP), CEO compensation $\left(C E O_{-} C O M P\right)$ and corporate governance (CEOICHAIR, OUTSIDE, BOARDSIZE, AUDITSIZE and TOPOWN) and conservatism measures (CSCORE, CONACC and CONBM). Except for CSCORE, conservatism measures (CONACC and CONBM) are positively correlated with DIR_COMP, which is in accordance with our expectation. Based on the positive association, we notice that equity-based compensation to outside directors increases the conservatism level of a firm. CEO_COMP and CONBM (CSCORE and CONACC) are positively (negatively) related to each other. As we mentioned above, the positive relation represents interest alignment between managers and shareholders but the negative relation denotes that managers act opportunistically to advocate their own benefits.

In addition, we also find a negative correlation between CSCORE (CONACC) and CEO/CHAIR. Since the duality of the CEO and Chairman exhibits weak corporate governance, the level of conservatism is negatively associated with CEO/CHAIR. The positive correlation between CONACC and OUTSIDE shows that stronger corporate governance with a higher proportion of outside directors in the board (e.g., Ajinkya et al. 2005, etc.) boosts the level of conservatism. Moreover, BOARDSIZE and AUDITSIZE are negatively related to conservatism measures (CSCORE and CONACC) as Yermack (1996) explained that a small board is more efficient and effective in monitoring. Lastly, the positive association between TOPOWN and CSCORE suggests that the level of conservatism is higher when the managers' ownership is higher due to the interest alignment between top managers and shareholders.

Table 3: Pearson Correlations among Variables Related

to Outside Board Members' Equity-based Compensation, Corporate Governance and Conservatism measures

\begin{tabular}{|c|c|c|c|c|c|c|c|}
\hline & DIR_COMP & CEO_COMP & CEO/CHAIR & OUTSIDE & BOARDSIZE & AUDITSIZE & TOPOWN \\
\hline CSCORE & $-0.0652 * * *$ & $-0.2702 * * *$ & $-0.1405 * * *$ & $-0.0637 * * *$ & $-0.4714 * * *$ & -0.2455 *** & $0.1383 * * *$ \\
\hline CONACC & $0.1067 * * *$ & $-0.0385 * * *$ & $-0.0589 * * *$ & $0.0404 * *$ & $-0.1063 * * *$ & $-0.1206 * * *$ & -0.0174 \\
\hline CONBM & $0.1388 * * *$ & 0.1810 **** & $0.0337^{*}$ & 0.0071 & $0.0631 * * *$ & 0.0216 & -0.0051 \\
\hline CONRANK1 & $0.1355 * * *$ & $-0.1106 * * *$ & $-0.1112 * * *$ & $-0.0366 * *$ & $-0.3613 * * *$ & $-0.2586 * * *$ & $0.0913 * * *$ \\
\hline CONRANK2 & $0.2258 * * *$ & $0.1038 * * *$ & -0.0172 & 0.0111 & $-0.0511 * * *$ & $-0.0998 * * *$ & -0.0025 \\
\hline
\end{tabular}

CSCORE = conservatism measure in Khan and Watts (2009); CONACC = (income before extraordinary items - cash flows from operations + depreciation expense) divided by average total assets (e.g., Givoly and Hayn, 2000); CONBM = book-to-market ratio multiplied by negative one (-1) (e.g., Beaver and Ryan, 2000); CONRANK1 = Average rank of CSCORE, CONACC, and CONBM; CONRANK2 = Average rank of CONACC and CONBM;DIR_COMP = ratio of total equity-based compensation to outside directors over total compensation to outside directors in a firm during the fiscal year (i.e. total equity-based incentives / total incentives); $C E O \_C O M P=$ ratio of total equity-based compensation to CEO over total compensation to CEO; $C E O / C H A I R$ $=1$ if the CEO also holds chairman of the board, and 0 otherwise; OUTSIDE = total number of independent outside directors over total number of directors; BOARDSIZE $=\log$ of total number of directors in a board; AUDITSIZE = log of total number of directors in audit committee; TOPOWN = the percentage of total shares held by top five executives to total outstanding shares; $* * *, * *$, and $*$ denote significance of parameter estimates at the $0.01,0.05$, and 0.10 levels, respectively.

\subsection{Results for multivariate tests}

Table 4 contains the multivariate regression results for conservatism levels. The results are based on the $O L S$ regressions. We are especially interested in DIR_COMP. From column 1 to column 5, the results show that the estimated coefficients of DIR_COMP are positive and statistically significant in all cases. These results support our conjecture. Specifically, firms with more equity-based compensation to outside directors have a higher level of conditional conservatism (CSCORE) and unconditional conservatism (CONACC and CONBM). Among the five coefficients of CEO_COMP, except in column 3, four numbers are positive and statistically significant and this indicates that CEOs' interests are better aligned with shareholders given that they get paid with more equity-based compensation. So the CEOs with more equity-based compensation show more conservative behavior conditionally or unconditionally.

Regarding the corporate governance variables, the results are similar to Ahmed and Duellman (2007). In other words, five coefficients for CEO/CHAIR are all negative and most of them are significant. This relation indicates that weaker corporate governance result in a lower level of accounting conservatism. Most coefficients of 
OUTSIDE is significantly positive, meaning that stronger governance with outside directors enhances the level of accounting conservatism. In terms of the size of the board or audit committee, we have to seemingly conflict, yet plausible results. In case of BOARDSIZE, we find the positive relation between board size and conservatism level, which is consistent with Dalton et al. (1999) since larger boards might recommend better advice with more experience and more knowledge than small boards. AUDITSIZE, on the other hand, we have negative coefficients. We conclude that this might be a result of effective and efficient monitoring of small board evidenced by Yermack (1996). The coefficients of other control variables are also statistically significant and meet our anticipation.

\section{SENSITIVITY ANALYSES}

\subsection{Alternative measure of equity-based compensation}

For the sensitivity test, we employ an additional measure of equity-based compensation to outside directors. Thus far, we use the ratio of the value of equity-based compensation to the value of total compensation to the directors and CEOs (DIR_COMP and CEO_COMP). As a sensitivity test, we alternatively calculate the dollar amount of the equity-based compensation given to each outside director (DIR_RAMT). DIR_RAMT is the average amount of equity-based compensation to each outside director (the total amount of equity-based compensation to outside directors / the number of outside directors). The results in Table 5 coherently prove that DIR_RAMT and conservatism levels (CSCORE, CONACC, CONBM, CONRANK1 and CONRANK2) are positively correlated with each other (four among five coefficients concur with our expectations). ${ }^{5}$

\subsection{Audit committee equity-based compensation}

Audit committee members are primarily responsible for the financial reporting processes. In this situation, audit committee members will be more rigorously engaged in those activities to prevent the managers' misbehavior in financial reports, and encourage the managers to report in a more conservative way. Since audit committee members are wholly composed of outside directors after the adoption of SOX (2002), we especially focus on the compensation structure of the audit committee members and the level of conservatism.

We use the proportion and dollar amount of the equity-based compensation given to each audit committee member (AUDIT_COMP and AUDIT_RAMT). AUDIT_COMP and AUDIT_RAMT are similarly defined except we narrow down our focus to the case of audit committee members. The coefficients shown in Table 6 and Table 7 suggest qualitatively similar results, and we find that audit committee equity-based compensation generally helps increase the level of accounting conservatism (CSCORE, CONACC, CONBM, CONRANK1 and CONRANK2) are positively correlated with each other (four out of five consistent with our expectations).

\footnotetext{
${ }^{5}$ We also use the log value of totla equity-based compensation to directors and CEOs, instead of the ratio. Untabulated results are qualitatively similar.
} 


\begin{tabular}{|c|c|c|c|c|c|c|c|c|c|c|}
\hline \multirow[b]{2}{*}{ Intercept } & \multicolumn{2}{|c|}{$\begin{array}{l}\text { (Column 1) } \\
\text { CSCORE }\end{array}$} & \multicolumn{2}{|c|}{$\begin{array}{l}\text { (Column 2) } \\
\text { CONACC }\end{array}$} & \multicolumn{2}{|c|}{$\begin{array}{l}\text { (Column 3) } \\
\text { CONBM }\end{array}$} & \multicolumn{2}{|l|}{$\begin{array}{l}\text { Column 4) } \\
\text { CONRANK1 }\end{array}$} & \multicolumn{2}{|c|}{$\begin{array}{l}\text { Column 5) } \\
\text { CONRANK2 }\end{array}$} \\
\hline & 0.5326 & $(34.09) * * *$ & 0.0203 & $(3.12) * * *$ & -1.1860 & $(-15.34) * * *$ & 2307.0639 & $(32.61) * * *$ & 913.5917 & $(8.44)^{* * * *}$ \\
\hline DIR_COMP & 0.0117 & $(1.71)^{*}$ & 0.0132 & $(4.63) * * *$ & 0.0789 & $(2.32)^{* *}$ & 223.8683 & $(7.21)^{* * *}$ & 347.8973 & $(7.32)^{* * *}$ \\
\hline CEO_COMP & 0.0124 & $(2.10)^{* *}$ & -0.0071 & $(-2.88) * * *$ & 0.2090 & $(7.13)^{* * *}$ & 50.6011 & $(1.89)^{*}$ & 102.8164 & $(2.51)^{* *}$ \\
\hline CEO/CHAIR & -0.0057 & $(-2.01)^{* *}$ & -0.0027 & $(-2.32)^{* *}$ & 0.0120 & $(0.85)$ & -30.8654 & $(-2.41)^{* *}$ & -21.4401 & $(-1.09)$ \\
\hline OUTSIDE & 0.0649 & $(5.79)^{* * *}$ & 0.0166 & $(3.55) * * *$ & -0.0499 & $(-0.90)$ & 233.9560 & $(4.61)^{* * *}$ & 84.2803 & (1.09) \\
\hline BOARDSIZE & -0.0031 & $(-0.41)$ & -0.0051 & $(-1.61)$ & 0.1709 & $(4.52)^{* * *}$ & 61.1251 & $(1.77)^{*}$ & 107.2136 & $(2.03)^{* *}$ \\
\hline AUDITSIZE & 0.0099 & $(1.57)$ & -0.0107 & $(-4.10) * * *$ & 0.0288 & $(0.93)$ & -91.7992 & $(-3.24)^{* * *}$ & -144.3717 & $(-3.33) * * *$ \\
\hline TOPOWN (\%) & 0.0003 & $(1.22)$ & -0.0000 & $(-0.32)$ & 0.0018 & (1.49) & 1.6267 & $(1.50)$ & 1.8538 & $(1.12)$ \\
\hline SIZE & -0.0673 & $(-54.59)^{* * *}$ & -0.0015 & $(-2.90)^{* * *}$ & -0.0179 & $(-2.95)^{* * *}$ & -184.2810 & $(-33.23)^{* * *}$ & -40.3996 & $(-4.76) * * *$ \\
\hline$D E B T$ & -0.0894 & $(-10.06)^{* * *}$ & 0.0215 & $(5.81)^{* * *}$ & 0.2215 & $(5.04)^{* * *}$ & 326.5439 & $(8.12)^{* * *}$ & 614.2378 & $(9.99)^{* * * *}$ \\
\hline$C F O$ & -0.1632 & $(-8.60)^{* * *}$ & 0.0507 & $(6.41)^{* * *}$ & 1.4807 & $(15.77)^{* * *}$ & 1598.8499 & $(18.61)^{* * *}$ & 3013.4019 & $(22.94)^{* * *}$ \\
\hline CSALES & -0.0407 & $(-4.58) * * *$ & -0.0292 & $(-7.91)^{* * *}$ & 0.3395 & $(7.73)^{* * *}$ & -123.9838 & $(-3.08)^{* * *}$ & -44.6753 & $(-0.73)$ \\
\hline LITI & -0.0133 & $(-3.64) * * *$ & 0.0121 & $(7.96) * * *$ & 0.0942 & $(5.23)^{* * * *}$ & 163.8349 & $(9.94)^{* * *}$ & 284.3649 & $(11.28)^{* * *}$ \\
\hline BIG4 & -0.0018 & $(-0.30)$ & 0.0090 & $(3.67) * * *$ & -0.0221 & $(-0.76)$ & 78.3107 & $(2.93) * * *$ & 113.2554 & $(2.77)^{* * *}$ \\
\hline \# of obs. & 3,104 & & 3,104 & & 3,104 & & 3,104 & & 3,104 & \\
\hline Adjusted $\mathrm{R}^{2}$ & 0.6631 & & 0.0873 & & 0.1462 & & 0.4415 & & 0.2312 & \\
\hline
\end{tabular}

CSCORE = conservatism measure in Khan and Watts (2009); CONACC = (income before extraordinary items - cash flows from operations + depreciation expense) divided by average total assets (e.g., Givoly and Hayn, 2000); CONBM = book-to-market ratio multiplied by negative one (-1) (e.g., Beaver and Ryan, 2000); CONRANK1 = Average rank of CSCORE, CONACC, and CONBM; CONRANK2 = Average rank of CONACC and CONBM; DIR COMP = ratio of total equity-based compensation to outside directors over total compensation to outside directors in a firm during the fiscal year (i.e. total equity-based incentives / total incentives); $C E O \_C O M P=$ ratio of total equity-based compensation to $\mathrm{CEO}$ over total compensation to CEO; CEO/CHAIR = 1 if the CEO also holds chairman of the board, and 0 otherwise; $O U T S I D E=$ total number of independent outside directors over total number of directors; BOARDSIZE $=\log$ of total number of directors in a board; AUDITSIZE $=\log$ of total number of directors in audit committee; TOPOWN $=$ the percentage of total shares held by top five executives to total outstanding shares; SIZE $=\log$ of total assets; $D E B T=$ ratio of total long-term debt to total assets; $C F O=$ ratio of cash flow from operations to total assets; CSALES = annual percentage change in sales; LITI = 1 for SIC 2833-2836, 3570-3577, 3600-3674, 7371-7379, and 8731-8734, and 0 otherwise; $B I G 4=1$ if a firm audited by big 4 auditors, 0 otherwise.

(Asymptotic) $t$-statistics are in parentheses. $*^{* *}, * *$, and $*$ denote significance of parameter estimates at the $0.01,0.05$, and 0.10 levels, respectively. 


\begin{tabular}{|c|c|c|c|c|c|c|c|c|c|c|}
\hline & $\begin{array}{l}\text { (Column } \\
\text { CSCORE }\end{array}$ & & $\begin{array}{l}\text { (Column 2) } \\
\text { CONACC }\end{array}$ & & $\begin{array}{l}\text { (Column 3) } \\
\text { CONBM }\end{array}$ & & $\begin{array}{l}\text { (Column 4) } \\
\text { CONRANK1 }\end{array}$ & & $\begin{array}{l}\text { Column 5) } \\
\text { CONRANK2 }\end{array}$ & \\
\hline Intercept & 0.5345 & $(32.25) * * *$ & 0.0389 & $(5.66) * * *$ & -0.9855 & $(-12.00)^{* * *}$ & 2671.7044 & $(35.91)^{* * *}$ & 1500.3894 & $(13.20)^{* * *}$ \\
\hline$D I R \_R A M T$ & 0.0000 & $(0.74)$ & 0.0000 & $(6.68)^{* * *}$ & 0.0000 & $(1.88)^{*}$ & 0.1110 & $(8.99) * * *$ & 0.1684 & $(8.93)^{* * *}$ \\
\hline$C E \bar{O}_{-} R A M T$ & -0.0000 & $(-1.55)$ & -0.0000 & $(-0.84)$ & 0.0000 & $(6.26)^{* * *}$ & 0.0058 & $(3.54) * * *$ & 0.0116 & $(4.63)^{* * *}$ \\
\hline CEO/CHAIR & -0.0056 & $(-1.96) * *$ & -0.0024 & $(-2.07)^{* *}$ & 0.0063 & $(0.45)$ & -30.7937 & $(-2.42)^{* *}$ & -22.5272 & $(-1.16)$ \\
\hline OUTSIDE & 0.0667 & $(5.80)^{* * *}$ & 0.0095 & $(1.99)^{* *}$ & -0.0467 & $(-0.82)$ & 149.6976 & $(2.90)^{* * *}$ & -41.6043 & $(-0.53)$ \\
\hline BOARDSIZE & -0.0040 & $(-0.52)$ & -0.0083 & $(-2.62) * * *$ & 0.1713 & $(4.50) * * *$ & 21.3392 & $(0.62)$ & 48.4246 & $(0.92)$ \\
\hline AUDITSIZE & 0.0094 & $(1.51)$ & -0.0109 & $(-4.21)^{* * *}$ & 0.0302 & $(0.98)$ & -94.3283 & $(-3.36) * * *$ & -148.0765 & $(-3.45)^{* * *}$ \\
\hline TOPOWN (\%) & 0.0001 & $(0.51)$ & -0.0000 & $(-0.01)$ & 0.0002 & $(0.16)$ & 0.9284 & $(0.89)$ & 0.6515 & $(0.41)$ \\
\hline SIZE & -0.0657 & $(-46.13)^{* * *}$ & -0.0026 & $(-4.35)^{* * *}$ & -0.0335 & $(4.75)^{* * *}$ & -207.7353 & $(-32.49) * * *$ & -80.2501 & $(-8.21)^{* * *}$ \\
\hline$D E B T$ & -0.0906 & $(-10.13)^{* * *}$ & 0.0230 & $(6.19)^{* * *}$ & 0.2503 & $(5.65)^{* * *}$ & 363.1663 & $(9.04) * * *$ & 675.8588 & $(11.01)^{* * *}$ \\
\hline$C F O$ & -0.1510 & $(-7.97)^{* * *}$ & 0.0453 & $(5.77)^{* * *}$ & 1.5059 & $(16.04)^{* * *}$ & 1554.4534 & $(18.28)^{* * *}$ & 2943.3497 & $(22.65)^{* * *}$ \\
\hline CSALES & -0.0377 & $(-4.27) * * *$ & -0.0294 & $(-8.02)^{* * * *}$ & 0.3492 & $(7.98)^{* * * *}$ & -117.8290 & $(-2.97) * * *$ & -35.0016 & $(-0.58)$ \\
\hline LITI & -0.0118 & $(-3.24) * * *$ & 0.0110 & $(7.27)^{* * *}$ & 0.0950 & $(5.24)^{* * *}$ & 152.3297 & $(9.27) * * *$ & 266.5990 & $(10.62)^{* * *}$ \\
\hline$B I G 4$ & -0.0007 & $(-0.13)$ & 0.0092 & $(3.77) * * *$ & 0.0026 & $(0.09)$ & 97.6286 & $(3.69) * * *$ & 146.4954 & $(3.63)^{* * *}$ \\
\hline \# of obs. & 3,104 & & 3,104 & & 3,104 & & 3,104 & & 3,104 & \\
\hline Adjusted $\mathrm{R}^{2}$ & 0.6624 & & 0.0924 & & 0.1429 & & 0.4502 & & 0.2446 & \\
\hline
\end{tabular}

CSCORE = conservatism measure in Khan and Watts (2009); CONACC = (income before extraordinary items - cash flows from operations + depreciation expense) divided by average total assets (e.g., Givoly and Hayn, 2000); CONBM = book-to-market ratio multiplied by negative one (-1) (e.g., Beaver and Ryan, 2000); CONRANK1 = Average rank of CSCORE, CONACC, and CONBM; CONRANK2 = Average rank of CONACC and CONBM; DIR RAMT = average amount of equity-based incentives to each director in a firm during the fiscal year; $C E O \_R A M T=$ total amount of equity-based incentives to CEO in a firm during the fiscal year; $C E O / C H A I R=1$ if the CEO also holds chairman of the board, and 0 otherwise; $O U T S I D E=$ total number of independent outside directors over total number of directors; BOARDSIZE = log of total number of directors in a board; $A U D I T S I Z E$ $=\log$ of total number of directors in audit committee; TOPOWN = the percentage of total shares held by top five executives to total outstanding shares; SIZE $=$ log of total assets; $D E B T=$ ratio of total long-term debt to total assets; $C F O=$ ratio of cash flow from operations to total assets; CSALES = annual percentage change in sales; $L I T I=1$ for SIC 2833 2836, 3570-3577, 3600-3674, 7371-7379, and 8731-8734, and 0 otherwise; BIG4 = 1 if a firm audited by big4 auditors, 0 otherwise.

(Asymptotic) $t$-statistics are in parentheses. $* * *, * *$, and $*$ denote significance of parameter estimates at the $0.01,0.05$, and 0.10 levels, respectively. 


\begin{tabular}{|c|c|c|c|c|c|c|c|c|c|c|}
\hline & $\begin{array}{l}\text { (Column } 1 \\
\text { CSCORE }\end{array}$ & & $\begin{array}{l}\text { (Column } 2 \\
\text { CONACC }\end{array}$ & & $\begin{array}{l}\text { (Column } 3 \\
\text { CONBM }\end{array}$ & & $\begin{array}{l}\text { (Column 4) } \\
\text { CONRANK1 }\end{array}$ & & $\begin{array}{l}\text { (Column 5) } \\
\text { CONRANK2 }\end{array}$ & \\
\hline Intercept & 0.5333 & $(34.16)^{* * *}$ & 0.0205 & $(3.16) * * *$ & -1.1855 & $(-15.34)^{* * *}$ & 2312.0764 & $(32.69) * * *$ & 918.3164 & $(8.49)^{* * *}$ \\
\hline AUDIT_COMP & 0.0098 & $(1.45)$ & 0.0128 & $(4.53)^{* * * *}$ & 0.0785 & $(2.34)^{* *}$ & 213.7493 & $(6.95)^{* * *}$ & 340.3201 & $(7.24)^{* * *}$ \\
\hline CEO_C̄ & 0.0126 & $(2.12)^{* *}$ & -0.0071 & $(-2.87)^{* * *}$ & 0.2090 & $(7.13)^{* * *}$ & 51.4071 & $(1.92)^{*}$ & 103.2976 & $(2.52) * *$ \\
\hline CEO/CHAIR & -0.0057 & $(-2.00) * *$ & -0.0027 & $(-2.29) * *$ & 0.0121 & $(0.87)$ & -30.2595 & $(-2.36) * *$ & -20.5558 & $(-1.05)$ \\
\hline OUTSIDE & 0.0652 & $(5.82)^{* * *}$ & 0.0168 & $(3.60) * * *$ & -0.0487 & $(-0.88)$ & 238.0934 & $(4.69)^{* * * *}$ & 89.9859 & (1.16) \\
\hline BOARDSIZE & -0.0031 & $(-0.41)$ & -0.0050 & $(-1.58)$ & 0.1717 & $(4.54)^{* * * *}$ & 62.7856 & $(1.81)^{*}$ & 110.2887 & $(2.08)^{* * *}$ \\
\hline AUDITSIZE & 0.0095 & $(1.52)$ & -0.0110 & $(-4.23) * * *$ & 0.0269 & $(0.87)$ & -97.6499 & $(-3.45) * * *$ & -153.1553 & $(-3.54) * * *$ \\
\hline TOPOWN (\%) & 0.0003 & (1.19) & -0.0000 & $(-0.34)$ & 0.0018 & (1.48) & 1.5870 & $(1.47)$ & 1.8186 & (1.10) \\
\hline SIZE & -0.0673 & $(-54.93) * * *$ & -0.0015 & $(-2.88) * * *$ & -0.0179 & $(-2.95) * * *$ & -184.0471 & $(-33.17)^{* * *}$ & -40.1202 & $(-4.73) * * *$ \\
\hline$D E B T$ & -0.0894 & $(-10.06)^{* * *}$ & 0.0216 & $(5.83)^{* * *}$ & 0.2220 & $(5.05)^{* * *}$ & 327.5693 & $(8.14)^{* * *}$ & 616.1026 & $(10.01)^{* * *}$ \\
\hline$C F O$ & -0.1622 & $(-8.56)^{* * *}$ & 0.0510 & $(6.46)^{* * *}$ & 1.4819 & $(15.80)^{* * *}$ & 1606.2096 & $(18.71)^{* * *}$ & 3021.4097 & $(23.02)^{* * *}$ \\
\hline CSALES & -0.0404 & $(-4.55) * * *$ & -0.0291 & $(-7.88) * * *$ & 0.3398 & $(7.74) * * *$ & -121.7001 & $(-3.03) * * *$ & -42.4538 & $(-0.69)$ \\
\hline LITI & -0.0131 & $(-3.61)^{* * *}$ & 0.0121 & $(7.96)^{* * *}$ & 0.0940 & $(5.22)^{* * *}$ & 164.1185 & $(9.95)^{* * *}$ & 284.1814 & $(11.27)^{* * *}$ \\
\hline$B I G 4$ & -0.0017 & $(-0.29)$ & 0.0090 & $(3.65)^{* * *}$ & -0.0225 & $(-0.77)$ & 77.8040 & $(2.91)^{* * *}$ & 112.0236 & $(2.74)^{* * *}$ \\
\hline \# of obs. & 3,104 & & 3,104 & & 3,104 & & 3,104 & & 3,104 & \\
\hline Adjusted $\mathrm{R}^{2}$ & 0.6630 & & 0.0870 & & 0.1462 & & 0.4409 & & 0.2309 & \\
\hline
\end{tabular}

CSCORE = conservatism measure in Khan and Watts (2009); CONACC = (income before extraordinary items - cash flows from operations + depreciation expense) divided by average total assets (e.g., Givoly and Hayn, 2000); CONBM = book-to-market ratio multiplied by negative one (-1) (e.g., Beaver and Ryan, 2000); CONRANK1 = Average rank of CSCORE, CONACC, and CONBM; CONRANK2 = Average rank of CONACC and CONBM; AUDIT COMP = ratio of total equity-based compensation to audit committee members over total compensation to audit committee members in a firm during the fiscal year (i.e. total equity-based incentives / total incentives); $C E O \_C O M P=$ ratio of total equity-based compensation to CEO over total compensation to CEO; CEO/CHAIR $=1$ if the CEO also holds chairman of the board, and 0 otherwise; $O U T S I D E=$ total number of independent outside directors over total number of directors; BOARDSIZE $=\log$ of total number of directors in a board; AUDITSIZE $=\log$ of total number of directors in audit committee; TOPOWN = the percentage of total shares held by top five executives to total outstanding shares; SIZE = log of total assets; $D E B T=$ ratio of total long-term debt to total assets; $C F O=$ ratio of cash flow from operations to total assets; CSALES = annual percentage change in sales; LITI = 1 for SIC 2833-2836, 3570-3577, 3600-3674, 73717379, and 8731-8734, and 0 otherwise; $B I G 4=1$ if a firm audited by big4 auditors, 0 otherwise.

(Asymptotic) $t$-statistics are in parentheses. $* * *, * *$, and $*$ denote significance of parameter estimates at the $0.01,0.05$, and 0.10 levels, respectively. 


\begin{tabular}{|c|c|c|c|c|c|c|c|c|c|c|}
\hline & $\begin{array}{l}\text { (Column } \\
\text { CSCORE }\end{array}$ & & $\begin{array}{l}\text { (Column } 2 \\
\text { CONACC }\end{array}$ & & $\begin{array}{l}\text { (Column } 3 \\
\text { CONBM }\end{array}$ & & $\begin{array}{l}\text { (Column 4) } \\
\text { CONRANK1 }\end{array}$ & & $\begin{array}{l}\text { (Column 5) } \\
\text { CONRANK2 }\end{array}$ & \\
\hline Intercept & 0.5326 & $(33.24) * * *$ & 0.0322 & $(4.85)^{* * *}$ & -1.0203 & $(-12.85)^{* * *}$ & 2552.9752 & $(35.42)^{* * *}$ & 1322.6081 & $(12.01)^{* * *}$ \\
\hline$A U D I T_{-} R A M T$ & 0.0000 & $(0.79)$ & 0.0000 & $(7.93)^{* * *}$ & 0.0000 & $(0.90)$ & 0.1623 & $(8.18)^{* * *}$ & 0.2519 & $(8.31)^{* * *}$ \\
\hline$C E O \_R A M T$ & -0.0000 & $(-1.56)$ & -0.0000 & $(-1.06)$ & 0.0000 & $(6.44) * * *$ & 0.0061 & $(3.69) * * *$ & 0.0119 & $(4.75)^{* * *}$ \\
\hline CEO/CHAIR & -0.0055 & $(-1.95)^{*}$ & -0.0023 & $(-1.93)^{*}$ & 0.0063 & $(0.45)$ & -29.2601 & $(-2.30)^{* *}$ & -20.0877 & $(-1.03)$ \\
\hline OUTSIDE & 0.0679 & $(6.06) * * *$ & 0.0138 & $(2.97)^{* * *}$ & -0.0259 & $(-0.47)$ & 222.9978 & $(4.42) * * *$ & 68.3612 & $(0.89)$ \\
\hline BOARDSIZE & -0.0029 & $(-0.38)$ & -0.0039 & $(-1.22)$ & 0.1821 & $(4.79) * * *$ & 79.5050 & $(2.31)^{* *}$ & 137.5145 & $(2.61)^{* * *}$ \\
\hline AUDITSIZE & 0.0082 & $(1.28)$ & -0.0159 & $(-6.03)^{* * *}$ & 0.0221 & $(0.70)$ & -152.7716 & $(-5.31) * * *$ & -238.4521 & $(-5.43) * * *$ \\
\hline TOPOWN (\%) & 0.0001 & $(0.52)$ & 0.0000 & $(0.12)$ & 0.0002 & $(0.14)$ & 0.9956 & $(0.95)$ & 0.7665 & $(0.48)$ \\
\hline SIZE & -0.0657 & $(-46.56)^{* * *}$ & -0.0025 & $(-4.25)^{* * *}$ & -0.0317 & $(-4.54)^{* * *}$ & -203.8858 & $(-32.13) * * *$ & -74.6998 & $(-7.71) * * *$ \\
\hline$D E B T$ & -0.0907 & $(-10.15)^{* * *}$ & 0.0227 & $(6.14) * * *$ & 0.2467 & $(5.57) * * *$ & 354.8070 & $(8.83)^{* * *}$ & 663.7035 & $(10.81)^{* * *}$ \\
\hline$C F O$ & -0.1511 & $(-7.98) * * *$ & 0.0440 & $(5.62)^{* * *}$ & 1.5203 & $(16.20)^{* * *}$ & 1566.8195 & $(18.39)^{* * *}$ & 2958.4233 & $(22.74)^{* * *}$ \\
\hline CSALES & -0.0378 & $(-4.28) * * *$ & -0.0297 & $(-8.13)^{* * *}$ & 0.3525 & $(8.05)^{* * *}$ & -115.3834 & $(-2.90)^{* * *}$ & -32.1501 & $(-0.53)$ \\
\hline LITI & -0.0118 & $(-3.24)^{* * *}$ & 0.0110 & $(7.26)^{* * *}$ & 0.0983 & $(5.44) * * *$ & 157.3003 & $(9.59)^{* * *}$ & 273.4465 & $(10.91)^{* * *}$ \\
\hline BIG4 & -0.0008 & $(-0.14)$ & 0.0090 & $(3.68) * * *$ & 0.0025 & $(0.09)$ & 95.3390 & $(3.60) * * *$ & 142.8747 & $(3.53)^{* * *}$ \\
\hline \# of obs. & 3,104 & & 3,104 & & 3,104 & & 3,104 & & 3,104 & \\
\hline Adjusted $\mathrm{R}^{2}$ & 0.6625 & & 0.0977 & & 0.1422 & & 0.4478 & & 0.2420 & \\
\hline
\end{tabular}

CSCORE = conservatism measure in Khan and Watts (2009); CONACC = (income before extraordinary items - cash flows from operations + depreciation expense) divided by average total assets (e.g., Givoly and Hayn, 2000); CONBM = book-to-market ratio multiplied by negative one (-1) (e.g., Beaver and Ryan, 2000); CONRANK1 = Average rank of CSCORE, CONACC, and CONBM; CONRANK2 = Average rank of CONACC and CONBM; AUDIT RAMT = average amount of equity-based incentives to each director in audit committee during the fiscal year; $C E O \_R A M T=$ total amount of equity-based incentives to CEO in a firm during the fiscal year; $C E O / C H A I R=1$ if the CEO also holds chairman of the board, and 0 otherwise; OUTSIDE = total number of independent outside directors over total number of directors; BOARDSIZE $=$ log of total number of directors in a board; $A U D I T S I Z E=\log$ of total number of directors in audit committee; TOPOWN = the percentage of total shares held by top five executives to total outstanding shares; SIZE $=$ log of total assets; $D E B T=$ ratio of total long-term debt to total assets; $C F O=$ ratio of cash flow from operations to total assets; $C S A L E S=$ annual percentage change in sales; $L I T I=1$ for SIC 2833-2836, 3570-3577, 3600-3674, 7371-7379, and 8731-8734, and 0 otherwise; BIG4 = 1 if a firm audited by big4 auditors, 0 otherwise.

(Asymptotic) $t$-statistics are in parentheses. $* * *, * *$, and $*$ denote significance of parameter estimates at the $0.01,0.05$, and 0.10 levels, respectively. 


\section{SUMMARY AND CONCLUSION}

This paper investigates the relationship between accounting conservatism and the equity-based compensation to outside directors. We find that the proportion of equity-based compensation to outside directors is positively associated with the level of conservatism. These results hold after controlling for general corporate governance measures or other general variables that possibly affect accounting conservatism. The results are also robust to additional tests using the amount of equity-based compensation instead of the proportion, and using both the proportion and amount of equity-based compensation to audit committee members as a substitute for the full board of directors. Therefore, our results provide evidence that the equity-based compensation to outside directors strengthens the alignment of directors with shareholders. Overall, our findings are consistent with the fact that the board of directors is interested in accounting conservatism of the firm as a way of reducing the information asymmetry between managers and shareholders. This paper also can provide supplementary evidence that equitybased compensation is one possible tool for improving corporate governance structure.

\section{AUTHOR INFORMATION}

Kyunbeom Jeong is Ph.D. candidate of Accounting at Korea Advanced Institute of Science and Technology (KAIST) in Korea. E-mail: $\underline{\text { future805@business.kaist.ac.kr }}$

Hyungtae Kim is Ph.D. candidate of Accounting at Korea Advanced Institute of Science and Technology (KAIST) in Korea. E-mail: forses@ business.kaist.ac.kr (Corresponding author)

\section{REFERENCES}

1. Aboody, D., \& Kasznik, R. (2000). CEO stock option awards and the Timing of Corporate Voluntary Disclosures. Journal of Accounting and Economics, 29, 73-100.

2. Ahmed, A., Billings, B., Morton, R. \& Stanford-Harris, M. (2002). The role of accounting conservatism in mitigating bondholder-shareholder conflicts over dividend policy and in reducing debt costs. The Accounting Review, 77, 867-890.

3. Ahmed, K., Hossain, M., \& Adams, M. (2006). The effects of board composition and board size on the informativeness of annual accounting earnings. Corporate governance: An International Review, 14, 418431.

4. Ahmed, A., \& Duellman, S. (2007). Accounting conservatism and board of director characteristics: an empirical analysis. Journal of Accounting and Economics, 43, 411-437.

5. Ajinkya, B., Bhojraj, S., \& Sengupta, P. (2005). The Association between outside directors, institutional investors and the properties of management earnings forecasts. Journal of Accounting Research, 43, 343376.

6. Ali, A., Chen, T., \& Radhakrishnan, S. (2007). Corporate disclosures by family firms. Journal of Accounting and Economics, 44, 238-286.

7. Armstrong, C., Jagolinzer, A., \& Larcker, D. (2009). Chief executive officer equity incentives and accounting irregularities. Journal of Accounting Research, 48, 225-271.

8. Basu, S. (1997). The conservatism principle and the asymmetric timeliness of earnings. Journal of Accounting and Economics, 24, 3-37.

9. Basu, S., Hwang, L., \& Jan, C. (2000). Differences in conservatism between big eight and non-big eight auditors. Working paper, City university of New York and California State University.

10. Beasley, M. (1996). An empirical analysis of the relation between the board of director composition and financial statement fraud. The Accounting Review, 71, 443-465.

11. Beaver, W., \& Ryan, S. (2000). Biases and lags in book value and their effects on the ability of the bookto-market ratio to predict book return on equity. Journal of Accounting Research, 38, 127-148.

12. Bedard, J., Chtourou, S., \& Courteau, L. (2004). The effect of audit committee expertise, independence, and activity on aggressive earnings management. Auditing: A Journal of Practice and Theory, 23, 15-35.

13. Beekes, W., Pope, P., \& Young, S. (2004). The link between earnings timeliness, earnings conservatism and board composition: evidence from the UK. Corporate Governance: An International Review, 12, 47-59. 
14. Beekes, W., \& Brown, P. (2006). Do better-governed Australian firms make more informative disclosures? Journal of Business Finance and Accounting, 33,420-455.

15. Bergstresser, D., \& Philippon, T. (2006). Manager incentives and earnings management. Journal of Financial Economics, 80, 511-529.

16. Cordeiro, J., Veliyath, R., \& Neubaum, D. (2005). Incentives for monitors: Directors stock-based compensation and firm performance. Journal of Applied Business Research, 21, 81-90.

17. Dalton, D., Daily, C., Johnson, J., \& Ellstrand, A. (1999). Number of directors and financial performance: a meta-analysis. Academy of Management Journal, 42. 674-686.

18. Davison, R., Goodwin-Stewart, J., \& Kent, P. (2005). Internal governance structures and earnings management. Accounting and Finance, 45, 241-267.

19. Fama, E. F., \& Jensen, M. C. (1983). Separation of ownership and control. Journal of Law and Economics, 26, 301-325.

20. Fich, E., \& Shivdasani, A. (2005). The impact of stock-option compensation for outside directors on firm value. Journal of Business, 78, 2229-2254.

21. Francis, J. R., Philbrick, D., \& Schipper, K. (1994). Shareholder litigation and corporate disclosures. Journal of Accounting Research, 32, 137-164.

22. Givoly, D., \& Hayn, C. (2000). The changing time-series properties of earnings, cash flows and accruals: has financial reporting become more conservative? Journal of Accounting and Economics, 29, 287-320.

23. Hui, K., Matsunaga, S., \& Morse, D. (2009). The impact of conservatism on management earnings forecasts. Journal of Accounting and Economics, 47, 192-207.

24. Jensen, M., \& Meckling, W. (1976). Theory of the firm: Managerial behavior, agency costs and ownership structure. Journal of Financial Economics, 33, 375-400.

25. Karamanou, I., \& Vafeas, N. (2005). The association between corporate boards, audit committees, and management earnings forecasts: An empirical analysis. Journal of Accounting Research, 43, 453-486.

26. Klein, A. (2002). Audit committee, board of director characteristics and earnings management. Journal of Accounting and Economics, 33, 375-400.

27. Khan, M., \& Watts, R. (2009). Estimation and empirical properties of a firm-year measure of accounting conservatism. Journal of Accounting and Economics, 48, 132-150.

28. Krishnan, G., \& Visvanathan, G. (2008). Do auditors price audit committee's expertise? The case of accounting versus non-accounting financial experts, Journal of Accounting, Auditing and Finance, 24, 115 144.

29. LaFond, R., \& Watts, R. (2008). The information role of conservatism. The Accounting Review, 83, 447478.

30. Linn, S. C., \& Park, D. (2005). Outside director compensation policy and the investment opportunity set. Journal of Corporate Finance, 11, 680-715.

31. Maug, E. (1997). Boards of directors and capital structure: Alternative forms of corporate restructuring. Journal of Corporate Finance, 2, 113-139.

32. Nagar, V., Nanda, D., \& Wysocki, P. (2003). Discretionary disclosure and stock-based incentives. Journal of Accounting and Economics, 34, 283-309.

33. Perry, T. (2000). Incentive compensation for outside directors and CEO turnover. Working paper.

34. Richardson, S., Sloan, R., Soliman, M., \& Tuna, I. (2005). Accrual reliability, earnings persistence and stock prices. Journal of Accounting and Economics, 39, 437-485.

35. Ryan, H., \& Wiggins, R. (2004). Who is in whose pocket? director compensation, board independence and barriers to effective monitoring. Journal of Financial Economics, 73, 497-524.

36. Vafeas, N. (1999). Board meeting frequency and firm performance. Journal of Financial Economics, 53, $113-142$.

37. Vafeas, N. (2000). Board structure and the informativeness of earnings. Journal of Accounting and Public Policy, 19, 139-160.

38. Warfield, T., Wild, J., \& Wild, K. (1995). Managerial ownership, accounting choices, and informativeness of earnings. Journal of Accounting and Economics, 20, 61-92.

39. Watts, R. (2003). Conservatism in accounting part I: explanations and implications. Accounting Horizon, 17, 207-221.

40. Watts, R. (2006). What has the invisible hand achieved. Working paper, Massachusetts Institute of Technology. 
41. Xie, B., Davidson, W., \& DaDalt, P. (2003). Earnings management and corporate governance: the role of the board and the audit committee. Journal of Corporate Finance, 9, 295-316.

42. Yeo, G., Tan, S., Ho, K., \& Chen, S. (2002). Corporate ownership structure and the informativeness of earnings. Journal of Business Finance and Accounting, 29, 1023-1046.

43. Yermack, D. (1996). Higher market valuation companies with a small board of directors. Journal of Financial Economics, 40, 185-211. 